Mary Cassatt: A Life 
This page intentionally left blank 


\title{
MARY CASSATT
}

\author{
賸 \\ A Life
}

Nancy Mowll Mathews

Yale University Press

New Haven and London 


\section{Copyright (C) 1994 by Nancy Mowll Mathews}

First published in the United States in 1994 by Villard Books, a division of Random House, Inc., and simultaneously in Canada by Random House of Canada Limited

Reissued in paperback in 1998 by Yale University Press

All rights reserved.

This book may not be reproduced, in whole or in part, including illustrations, in any form (beyond that copying permitted by Sections 107 and 108 of the U.S. Copyright Law and except by reviewers for the public press), without written permission from the publishers.

Set in Perpetua type by dix!

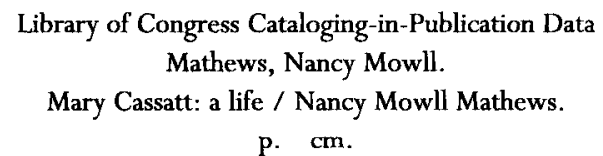

Originally published: 1st ed. New York : Villard Books, 1994. Includes bibliographical references and index.

ISBN 13: 978-0-300-07754-4 (pbk. : alk. paper)

1. Cassatt, Mary, 1844-1926. 2. Painters - United States-

Biography. I. Title.

ND237.C3M28 1998

$759.13-\mathrm{dc} 21$

[b]

$98-8028$

\section{CIP}

A catalogue record for this book is available from the British Library.

The paper in this book meets the guidelines for permanence and durability of the Committee on Production Guidelines for Book Longevity of the Council on Library Resources.

Printed in the United States of America 